\title{
"Practical aspects of assessing the efficiency of the modern system of public procurement in Ukraine"
}

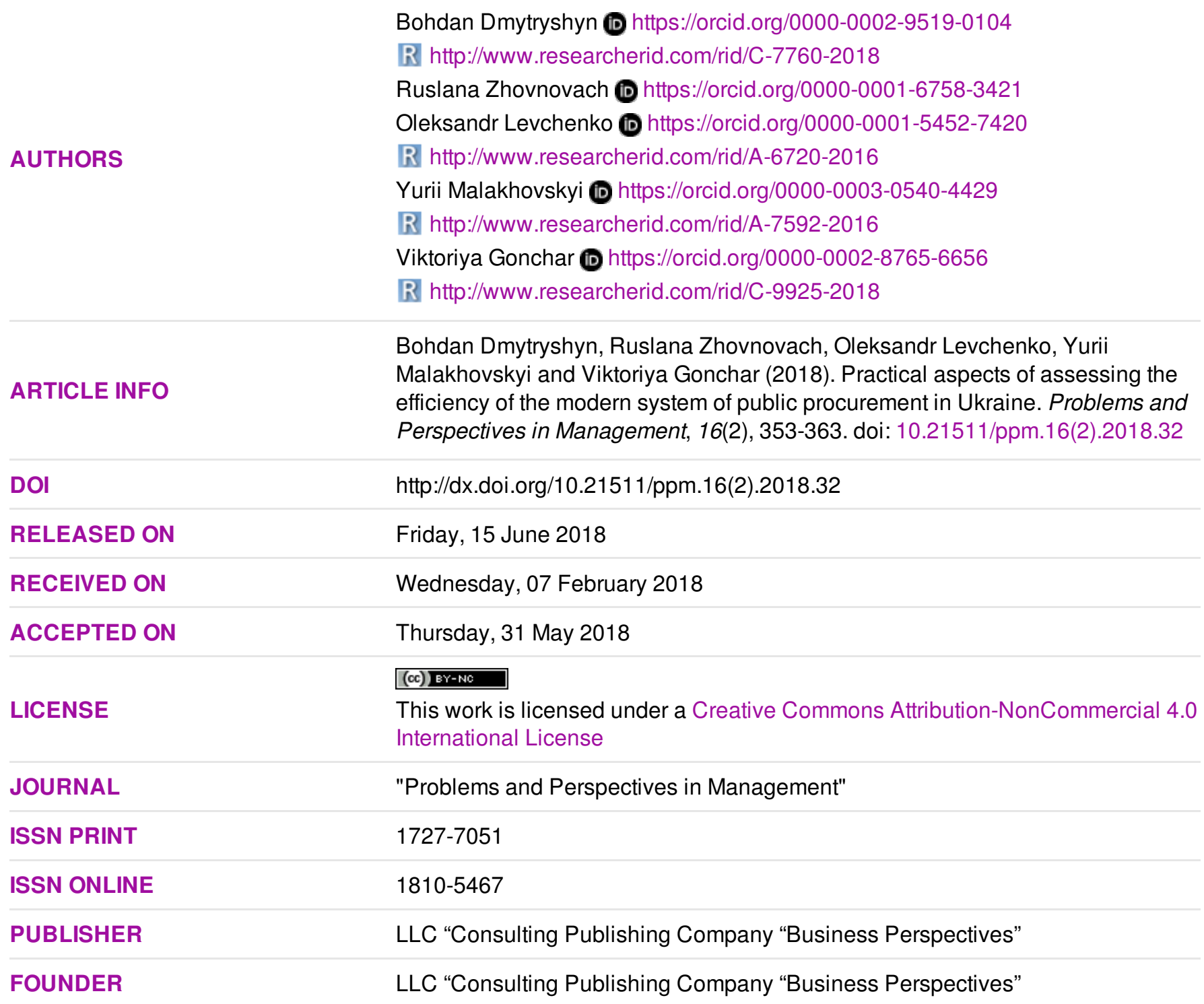

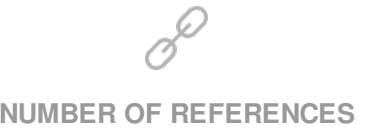

26
NUMBER OF FIGURES

2

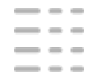

NUMBER OF TABLES

1

(C) The author(s) 2022. This publication is an open access article. 


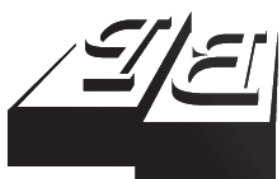

BUSINESS PERSPECTIVES

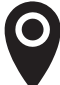

LLC "CPC "Business Perspectives" Hryhorii Skovoroda lane, 10, Sumy, 40022, Ukraine

www.businessperspectives.org

Received on: $7^{\text {th }}$ of February, 2018

Accepted on: $31^{\text {st }}$ of May, 2018

C Bohdan Dmytryshyn, Ruslana Zhovnovach, Oleksandr Levchenko, Yurii Malakhovskyi, Viktoriya Gonchar, 2018

Bohdan Dmytryshyn, Ph.D. in Economic Sciences, Associate Professor, Senior Lecturer, Department of Economic Theory, Marketing and Economic Cybernetics, Central Ukrainian National Technical University, Ukraine.

Ruslana Zhovnovach, Doctor of Economic Sciences, Associate Professor, Head of Department of Economic Theory, Marketing and Economic Cybernetics, Central Ukrainian National Technical University, Ukraine.

Oleksandr Levchenko, Doctor of Economic Sciences, Professor, Vice Rector on Scientific Research Activity Central Ukrainian National Technical University, Ukraine.

Yurii Malakhovskyi, Ph.D. in Economic Sciences, Associate Professor, Senior Lecturer, Department of Economics, Management and Business, Central Ukrainian National Technical University, Ukraine.

Viktoriya Gonchar, Doctor of Economi Sciences, Associate Professor, Head of Marketing and Business Administration Department, Pryazovskyi State Technical University, Ukraine.

\section{(ㄷ)(1) (8)}

This is an Open Access article, distributed under the terms of the Creative Commons Attribution-NonCommercial 4.0 International license, which permits re-use, distribution, and reproduction, provided the materials aren't used for commercial purposes and the original work is properly cited.
Bohdan Dmytryshyn (Ukraine), Ruslana Zhovnovach (Ukraine), Oleksandr Levchenko (Ukraine), Yurii Malakhovskyi (Ukraine), Viktoriya Gonchar (Ukraine)

\section{PRACTICAL ASPECTS OF ASSESSING THE EFFICIENCY OF THE MODERN SYSTEM OF PUBLIC PROCUREMENT IN UKRAINE}

\begin{abstract}
The issue of reforming the institute of state (public) procurement is one of the key directions of the modernization of the administrative sector of our state. Increasing the efficiency of this institute should be recognized as one of the conditions for ensuring stable economic growth. In this regard, issues relating to the assessment of the efficiency of the use of public funds are of particular interest. The indicators of the efficiency of the activity of the public procurement sector in Ukraine in the context of the introduction of the "ProZorro" electronic procurement system are calculated and analyzed. The existing works of the individual scientists in the direction of developing indicators of the efficiency that can be used to evaluate the results of the operation of the procurement logistics system in the public sector in Ukraine are generalized. As a result, approaches have been identified that can be used to determine the effectiveness of the participation of customers, private sector representatives and the system of electronic public procurement in general. On the basis of retrospective data of past years and the first half of the current year, a number of estimates of absolute and relative savings, as well as indicators of the effectiveness of the open bidding in the public sector of Ukraine have been identified. The dynamics of these indicators before and after the introduction of the "ProZorro" electronic procurement system was analyzed. The analysis shows that the first results of the functioning of the "ProZorro" system demonstrate the existence of negative trend of competition and reduction in the amount of savings in public funds. Ensuring high efficiency and competitiveness, integrity and transparency of the procurement process are the main tasks of the Ukrainian government in the field of public procurement. The authors argue that the introduction of the "ProZorro" system can help to solve them successfully, and the application of the analytics module enables to calculate the savings from the use of this system.
\end{abstract}

\section{Keywords}

public procurement, open bidding, the "ProZorro" system, efficiency

\section{JEL Classification D61, H19, H57}

\section{INTRODUCTION}

The $21^{\text {st }}$ century is an era of rapid development of information systems and technological progress, which, of course, requires reforming the state management sector with a view to its modernization, increasing efficiency and alignment with modern world standards (in particular, with the European ones in connection with the ratification of the Agreement on Association between Ukraine and the European Union as of June 27,2014$)$.

One of the priority directions of the reforming of the state administrative sector should be recognized as an institution of the state or public procurement, which has always been considered the most corrupt and ineffective in our country. At the same time, developed countries use public procurement as one of the most effective tools of the state aid system to ensure stable economic growth. Note that according to the 
Law of Ukraine "On State Aid to Business Entities", public procurement is a part of the system of state aid instruments for the national economy.

It should be noted that procurement is the main direction of using public funds in the world. The volume of public procurement in the European Union is an average of $14 \%$ of the gross domestic product per year (European Commission, 2017). In relation to the EU's GDP in 2015, this amount was about EUR 2700 billion (International Monetary Fund, 2016). According to the Ministry of Economic Development and Trade of Ukraine, the similar indicator was about USD 12 billion or 13\% of Ukraine's GDP in 2015 (The World Bank, 2017). Of course, the size of this procurement does not always indicate their effectiveness, since the sector in each country has its own corruption components. In this regard, the issue of assessing the effectiveness of using state funds in order to ensure the country's economic growth is actualized.

\section{LITERATURE REVIEW}

Existing studies of domestic and foreign scholars are devoted to both theory and practice of evaluating public procurement as a means of regulating the economy.

The study of public procurement in the EU countries, conducted by scientists from the European Commission, is based on a significant empirical basis (statistical database of contracts for the period 2006-2010, information on more than 7300 customers and interviews with 150 procurement specialists). The focus is on the contradiction between the objectives of increasing competition and reducing costs, between equity and transparency, and the flexibility of government regulation.

The work of Carlene van der Westhuizen (2015) is dedicated to public procurement in South Africa. However, the publication of the author is purely observational and does not contain analytical assessments of the effectiveness of the functioning of the system.

Urjumelashvili and Marghania (2015) indicate that the implementation of the electronic procurement system can save at least $10 \%$ of the procurement budget through increased efficiency and transparency. Researchers note the need to reform public procurement in Ukraine while justifying the idea, principles and architecture of the "ProZorro" system.

Yuzevych, Klyuvak, and Skrynkovsky (2017), in order to diagnose the process of interaction between the state and business and further optimization of the public procurement system, propose to apply a nonlinear canonical discriminant function with five parameters (coverage coefficients, autonomy, maintenance of own working capital, financial risk, profit ratio to net income from sales of products). The calculation of the diagnostic value of the information and the weight of the criteria was applied in assessing the competitiveness of the private joint-stock company "State Export-Import Bank of Ukraine".

Martynovych (2016) points out that an effective system of public procurement should be characterized by indicators such as operational efficiency, the level of bureaucracy, the size of the cost of maintaining the electronic system and the share of public procurement in the country's gross domestic product. However, for all of them, in addition to the last one, the author gives neither the calculation methodology nor the practical results.

A thorough investigation of corruption risks in the field of public procurement was carried out by Tosco (2017), Marlina Wati Ishak and Jamaliah Said (2015). Tosco considers it necessary to isolate corruption risks at macro, meso- and micro levels and justifies the feasibility of applying the method of quantification of these risks on the basis of the use of cluster analysis. At the same time, the answers of respondents-employees of the public administration are responding to the initial analytical information, but the issue of the contents of the questionnaires remains unsolved, the sample size and the statistical significance of the results are ungrounded. At the same time, Marlina Wati Ishak and Jamaliah Said consider the most important task to minimize the participation of lobbyists in the process of electronic procurement. 
Most researchers prefer the approaches based on assessing the efficiency of the procurement system through the overall cost savings (Melnykov, 2012, 2016; Golovanenko, 2016). However, the use of the indicator of cost savings only with fragments characterizes the result (efficiency), which may be non-objective because of the contradiction in determining the initial purchase price from the customer side.

At the same time, the issue of the effectiveness of the implementation and monitoring of the electronic procurement system remains highlighted not so much in both Ukrainian and foreign sources. In particular, in domestic literature, methods of estimating the effectiveness of the public procurement system at the present stage of its formation are rather poorly presented, as in the majority of them, they relate to the period until 2016, when procurement procedures were not yet foreseen through the "ProZorro" electronic system and the Law "On Public Procurement" did not come into force.

\section{METHODS}

The purpose of the scientific work is to generalize the existing developments of individual scientists in the direction of forming indicators of the efficiency that can be used to evaluate the results of the operation of the procurement logistics system in the public sector and the approbation them in practice (for example, the introduction of the "ProZorro" electronic procurement system).

The methodological foundations of the study include the conceptual foundations of the theory of public procurement, the concept of the effectiveness of the national economic system, the development of Ukrainian and foreign scientists in the field of public procurement management using the electronic system. To achieve this goal, the authors use the dialectical method of scientific knowledge and a number of general scientific and special research methods that are interrelated and consistently applied in accordance with the general logic of analysis: theoretical synthesis, analysis and synthesis, system analysis and statistical analysis, etc.

The monographic method was used for a detailed analysis of existing points of view of domestic and foreign theoretical scholars on the issues of re- search, as well as evaluation of the practice of public procurement as a means of state regulation of the economy by executive authorities.

The key to highlighting the chosen topic was a comparative approach for analyzing the phenomenon of public procurement and the conditions for their improvement abroad and in domestic practice, as well as a systematic approach that provided public procurement research as a mechanism consisting of interrelated elements and functioned on a clear basis defined principle.

A historical approach was presented as scientifically useful in order to identify the main factors and preconditions for the development of a competitive environment in the field of public procurement in countries with a developed market economy and in the context of transformations of the national economy in Ukraine.

The institutional method has been used in the study of key institutions for the development of the phenomenon of public procurement, analysis of the effectiveness and the role of legislation at all levels.

The structural and functional method has proved effective in the context of the study of the role of the state apparatus in the development of public procurement, as well as the definition of the functional purpose of the mechanism of concerted action of the public sector of the economy, participants in procurement procedures, supervisory and control bodies.

Content analysis and event analysis were used in the study of normative documents and factual materials, information presented in various media channels, including Internet resources on research issues.

\section{RESULTS}

The experience of the developed countries of the world shows that it is extremely important to create a system of public procurements with well-defined goals and means of their realization. Due to differences in the economic, social and political environment, each country and even individual 
state institutions may have their own priorities in public procurement policies. In environments where corruption is widespread, the public procurement system must focus more on ensuring the integrity and transparency of the procurement process. A government operating in a weak or diseased economy, that is, a chronic deficit of financial resources, can use public procurement as a powerful tool for economic development, but it is required to devote significant efforts to ensure high efficiency and competitive procurement.

In our country, the mechanism of public procurement is characterized by a number of principles referred to in Article 3 of the Law of Ukraine "On Public Procurement". Among them there is a lack of discrimination of participants and fair competition between them, maximum economy, efficiency, openness and transparency of procurements, objective evaluation of tender offers and prevention of corruption.

Capitalizing on the benefits of the digital revolution, the Ukrainian government is taking steps towards modernizing public administration, in particular by simplifying procedures and wider use of electronic means in the field of public procurement, which, in turn, aims to reduce the likelihood of corruption. Thus, one of the most important elements in the strategy of improving the efficiency of procurement logistics in the public sector, as well as reducing its corruption, is the introduction of the "ProZorro" system in 2016. The main purpose of this system is to prevent corruption by increasing the transparency of the market and creating a competitive environment in the field of public procurement for the best offer. This, in turn, leads to savings of budget funds and an increase of the efficiency of the functioning of the public procurement system in general.

From an institutional point of view, the main subjects in the procurement process can be divided into three groups: customers (represent the public sector of the economy); participants in procurement procedures (as a rule, they are representatives of the private sector); supervisory and control bodies. Accordingly, the effectiveness of the functioning of the public procurement system can be considered from different parties. The most important difference between the public sector and the private sector is the divergence in their goals. The purpose of a private enterprise is to obtain maximum profit, and the achievement of this goal can be objectively measured. In the public sector, the maximization of profits is replaced by the satisfaction of the interests of the public. It is extremely difficult to assess the direct economic effect of providing public services to the population. Therefore, the economic activity of the public sector can only be about the economical use of budget funds.

So, for the customer, the greatest value is the achievement of the maximum effect in the form of savings in the implementation of procurement.

Firstly, this is an indicator of the effect of saving money in the implementation of a separate procurement:

$$
E_{1}=V_{E}-V_{A},
$$

where $V_{E}$ - expected value (budget) of procurement (shows the maximum amount of money that can be spent by the customer to purchase the relevant subject); $V_{A}$ - actual value of the concluded agreement (determined by the results of the conducted procurement procedure).

Secondly, the indicator for determining the total savings that can be used to evaluate the functioning of the procurement system as a whole (or according to a significant number of procedures):

$$
E_{T}=\frac{\sum_{i=1}^{n} V_{E_{i}}-\sum_{i=1}^{n} V_{A_{i}}}{\sum_{i=1}^{n} V_{E_{i}}},
$$

where $n$ - number of procurement procedures $(i=1, \ldots, n)$.

It should be noted that the formulae (1) and (2) should be used only for competitive procedures of public procurement, the main of which, according to the former Law "On Implementation of State Procurement", and currently in force "On Public Procurement", is an open bidding procedure. Most regulatory legal acts in the field of public procurement regulate the very competitive bidding process, while non-competitive types of 
Table 1. Implementation of public procurement under the open bidding procedure in Ukraine during the period 2012-2017

\begin{tabular}{|c|c|c|c|c|c|c|c|}
\hline \multirow[b]{2}{*}{ Name of the indicator } & \multicolumn{5}{|c|}{ Before the "ProZorro" system is implemented } & \multicolumn{2}{|c|}{$\begin{array}{l}\text { After the "ProZorro" } \\
\text { system is implemented }\end{array}$} \\
\hline & 2012 & 2013 & 2014 & 2015 & $\begin{array}{c}2016 \\
\text { (January- } \\
\text { June) }\end{array}$ & $\begin{array}{c}2016 * \\
\text { (August- } \\
\text { December) }\end{array}$ & $\underset{\substack{2017^{*} \\
\text { (January- } \\
\text { June) }}}{-}$ \\
\hline $\begin{array}{l}\text { Total announcement of the results } \\
\text { of procurement procedures }\end{array}$ & 48,509 & 30,733 & 25,380 & 34,487 & 26,556 & 35,412 & 56,740 \\
\hline $\begin{array}{l}\text { Number of participants who have } \\
\text { submitted competitive bids }\end{array}$ & 126,582 & 82,584 & 57,262 & 78,865 & 48,272 & 48,311 & 20,080 \\
\hline $\begin{array}{l}\text { Total amount of money declared by } \\
\text { customers (expected value), UAH million }\end{array}$ & 239,107 & 119,745 & 75,822 & 90,982 & 84,417 & 37,944 & 109,720 \\
\hline $\begin{array}{l}\text { Total amount of funds on concluded } \\
\text { contracts (actual cost), UAH million }\end{array}$ & 208,240 & 95,981 & 54,932 & 78,278 & 64,171 & 34,317 & 100,840 \\
\hline Savings in public funds, UAH million & 30,867 & 23,764 & 20,890 & 12,704 & 20,246 & 3,627 & 8,880 \\
\hline Savings of public funds, $\%$ & 12.9 & 19.8 & 27.6 & 14.0 & 24.0 & 9.6 & 8.1 \\
\hline
\end{tabular}

Note: ${ }^{*}$ Incl. open bidding with publication in English.

procurement are exceptions with clearly defined limits of application. Because of this, the work of the "ProZorro" system is important to evaluate at competitive bidding.

The sample of data on the main factual indicators of the implementation of state (public by new law) procurement under the open bidding procedure and calculation of savings of budget funds is presented in Table 1.

As can be seen from Table 1, the maximum value of the savings rate in the application of open bidding procedures was reached in 2012 (UAH 30,867 million). This can be explained by the holding of Euro 2012 in our country. After 2012, the amounts of savings tended to decrease steadily, however, during the first half of 2016, UAH 20,246 million was saved, which is 1.6 times more than in the whole previous year.

At the same time, the most significant activity of customers could be observed in the months preceding the phased introduction of the Law "On Public Procurement" (from April 1, for central executive authorities and customers operating in certain spheres of management, and from August 1, 2016 - for all customers). This can be explained by the unwillingness of customers to changes and opening data during procedures, which provoked an increase in the number of purchase announcements in their usual way (that is, without the use of the electronic system). In general, the peak in
2016 was in March (21.85 thousand procedures), July (11.19 thousand procedures), and December (14.3 thousand procedures), while in 2015, it was in February and September (Figure 1).

In the first half of 2016, in conditions of expectation of the mandatory implementation of the "ProZorro" electronic procurement system for all state customers, the total amount of money declared by the customers (expected value) amounted to UAH 84.4 billion (for the whole previous year - by UAH 91 billion), and contracts were concluded for the amount of UAH 64.2 billion (for the whole previous year - by UAH 78.3 billion). Thus, the saving of public funds amounted to UAH 20.2 billion (this is UAH 7.5 billion more than in the previous year), but the number of participants who submitted competitive bids only amounted to 48.3 thousand (this is much lower than in previous years). Consequently, we can conclude a significant reduction in the level of competition in procurement procedures in the first half of 2016. At the same time, one of the key tasks of the new electronic "ProZorro" system is to increase the average number of participants.

In part, the lack of competition is conditioned by the need for public utilities purchasing from monopolists: an analysis of information on contracts concluded as a result of procurement procedures shows that the overwhelming majority among noncompetitive ones is procurement of utilities. Thus, in the period 2015-2016, a "negotiated pro- 


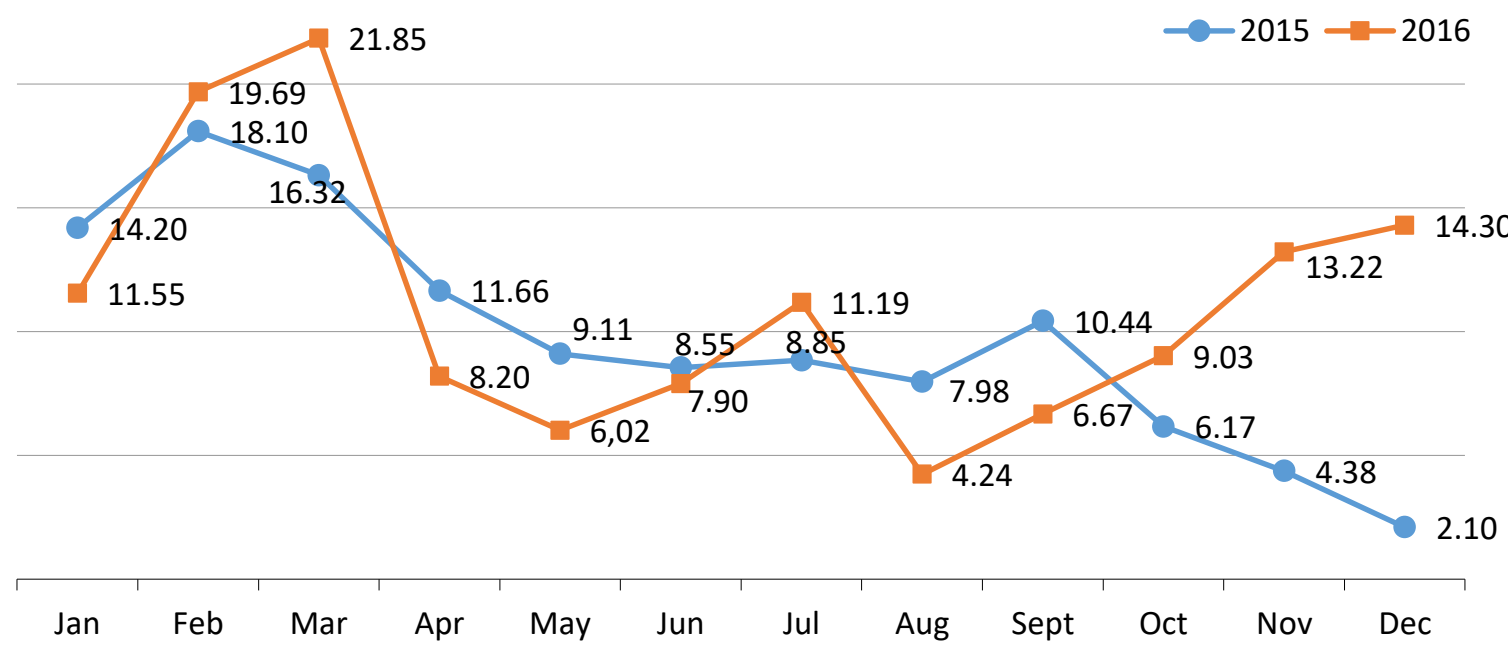

Figure 1. Procurement procedures announced in the period 2015-2016, ths.

curement procedure" appears, according to which exclusive (de facto, non-competitive) purchases of the state in monetary terms decreased from $48.5 \%$ in 2015 to $34.2 \%$ in 2016 (calculated on the basis of data of factual completed purchases). Also, in non-competitive procedures, quite often customers continue to purchase natural gas, taking into account the collisions of the legislative field with regard to the activities of gas suppliers at unregulated tariffs.

According to Transparency International, Ukrainian trend of competition in the "ProZorro" system in the second half of 2016 is generally negative. This assertion is based on a linear reduction of competition for the monthly sub-procurement and open bidding, which provided $98 \%$ of the price offers.

In the first half of 2017, there was a significant increase in the volume of public procurement through the "ProZorro" system (compared to August-December of the previous year), in particular, the total amount of funds under concluded contracts was almost three times higher than in August-December 2016. Total savings amounted to almost UAH 9 billion (in AugustDecember 2016 - UAH 3.6 billion) with the total number of announcements on open biddings of 56.7 thousand (in August-December 2016 - 35.4 thousand). So, as we see in the current year, the "ProZorro" system is becoming more popular among customers, although it became manda- tory for use in mid-2016. In general, we note that estimating the amount of data disclosure in "ProZorro" and calculating the effectiveness of its use are the subject of studies that are just beginning, since the system began to work only last year.

It should be noted that the estimated savings are significantly dependent on the number and volume of trades. In the period from 2012 to 2014, there was a reduction in them, respectively, the amount of savings decreased. In this regard, it is more appropriate to consider the dynamics of the specific savings indicator. As can be seen from Table 1, during the period from 2012 to 2014, the specific saving indicator tended to increase steadily (from $12.9 \%$ to $27.6 \%$ ). However, in 2015 , the value of this indicator dropped sharply to $14 \%$, as under more rigid budget constraints, customers were forced to set the expected value of procurement at a much lower level (compared with previous years). In addition, according to the State Statistics Service of Ukraine in 2015, the pace of price growth was $143.3 \%$, which had a very negative impact on both the solvency of the population and financial results of the business entities (in the negative expectations, private sector representatives were reluctant to go to lower their price offers).

It should be noted that the savings indicators E1 and $\mathrm{ET}$, in addition to reducing the price during 
Source: Built by the authors according to Derzhavna sluzhba statystyky Ukrainy, Ofitsiinyi sait modulia analityky systemy "Prozorro"

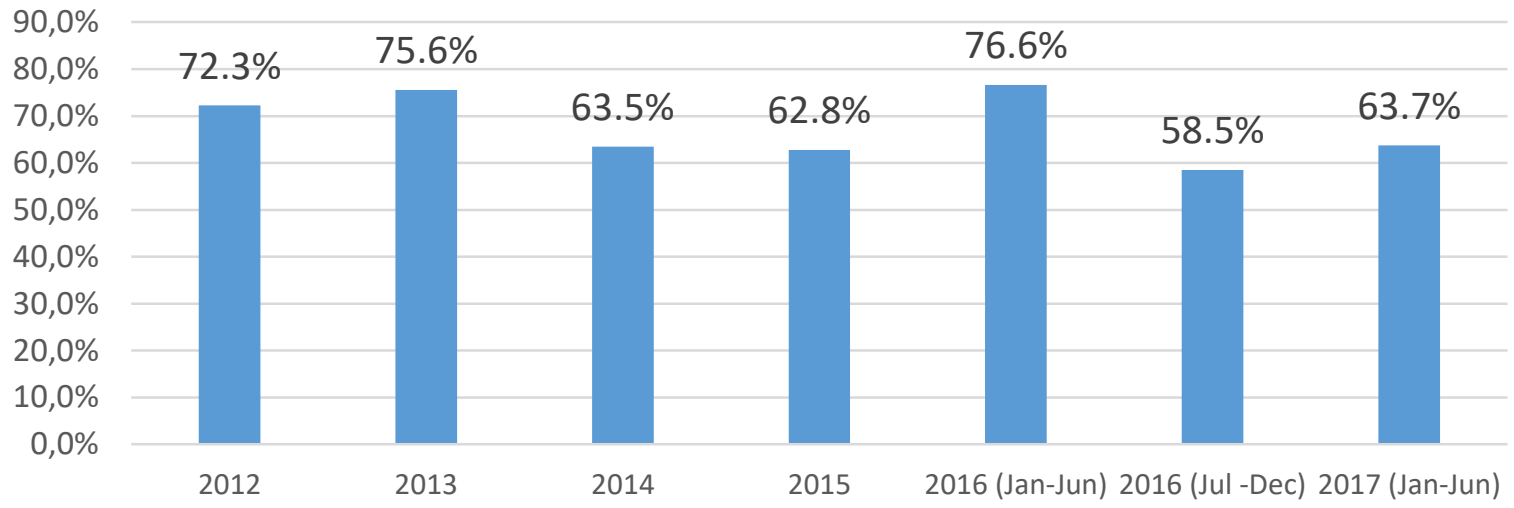

Figure 2. Dynamics of the indicator of the efficiency of open bidding in Ukraine, \%

the auction due to high competition in the trades, can also indicate a significantly overestimated expected cost of procurement and low level of planning. The Ministry of Economic Development and Trade of Ukraine expected that this indicator will decrease over time due to increased professionalism of customers and a more precise expectation of the value of the procurement item. Indeed, compared with the previous years, in the second half of 2016 - the first half of 2017, the specific saving rate of public funds dropped sharply (by $9.6 \%$ and $8.1 \%$, respectively).

The calculations show that the use of the indicator of the economy of public expenditures only by fragments characterizes a result that can be quite non-objective because of the contradiction in determining the initial contract price. It is important that the winner is chosen not only at the lowest proposed price, but also on the overall economic efficiency of the offer. Such an assessment can only be used for operational analysis, since competition, level of execution of orders, observance of the current legislation, etc. are not taken into account. Accordingly, there is a need to use a comprehensive indicator that takes into account direct and indirect economic effects.

An important component in the system for evaluating the effectiveness of public procurement is the analysis of the use of non-price criteria by customers. This is due to the fact that, according to both domestic and foreign legislation, tenders can be selected using a price criterion or a combination of quantitative and qualitative characteristics. For example, in the EU, the valuation by combined criteria is in $70 \%$ of the contracts. The lowest price criterion can only be used in small contracts. But the lack of clear understanding of the mechanism for evaluating bids with non-price criteria by the domestic customers complicates the application of such an approach in our country.

In addition to the traditional indicators of absolute and specific savings from the application of procurement procedures, the study proposes the calculation of the rate of the efficiency of trades (Er):

$$
E_{r}=\left(1-\frac{K_{\text {canceled }}}{K_{\text {declared }}}\right) \cdot 100 \%,
$$

where $K_{\text {canceled }}$ - number of cancelled purchasing procedures, $K_{\text {declared }}$ - the number of announced procurement procedures.

The logic of evaluating the efficiency of the procurement system using the indicator represented by formula (3) is to determine the proportion of procedures that were performed effectively (not canceled). The importance of this indicator lies in the fact that a significant number of canceled procedures mean the threat of untimely supply of procurement entities by the necessary goods, works or services. Also, the abolition of procurement procedures due to the lack of sufficient number of participants, if it occurs twice from the same procurement subject, is the reason for the use of the negotiation procedure. The latter is believed to be a major corruption risk, as the customer chooses the supplier subjectively.

The results of calculating the indicator of the efficiency of open bidding on the factual data of 
public procurement in Ukraine during the period 2012-2017 are shown in Figure 2.

As Figure 2 confirms, the dynamics of the indicator of the effectiveness of the application of competitive procurement procedures in Ukraine is rather unstable: if during the period 2013-2015, it significantly decreased (by 12.8), in the first half of 2016, growth was observed at 13.8 - up to $76.6 \%$. However, after the "ProZorro" system was implemented, the indicator of the efficiency of open bidding was expected to fall (in August-December 2016 to 58.5\%), although in the first half of 2017, we see an improvement of the efficiency of open bidding at 5.2.

Negative is the growth of the share of disqualifications in the secondary procurement and open bidding. Such a situation may adversely affect the involvement of potential suppliers.

Somewhat different are the approaches to assessing the effectiveness of participation in public procurement for participants in the relevant procedures.

Thus, according to Klyuvak (2017), the effectiveness of an electronic procurement contract with a state customer for an entrepreneur $\left(E_{e p}\right)$ can be determined taking into account the following parameters: the cost of electronic procurement $\left(C_{t p}\right)$, the cost of participation in the tender on the electronic platform $\left(C_{p a}\right)$, the cost of the electronic banking guarantee $\left(G_{e l}\right)$, the cost price of the unit of tender goods, services, works $\left(\mathrm{C}_{\text {prime }}\right)$, the volume of the tender $\left(Q_{\mathrm{psw}}\right)$, additional costs associated with personnel training, investing in information technology, etc. $\left(C_{\text {add }}\right)$, cash expenses due to adverse effects of bank guarantee (for example, the need for collateral or "freezing" of bank accounts) $\left(C_{\text {loss }}\right)$ :

$E_{e p}=\frac{C_{p a}+G_{e l}+\left(C_{p r i m e} \cdot Q_{p s w}\right)+C_{a d d}+C_{\text {loss }}}{C_{t p}} \cdot 100 \%$. (4)

Taking into account mentioned in Article 24 of the Law of Ukraine "On Public Procurement" the size of the provision of the tender offer and in Article 26 of the same law, the size of the provision of the implementation of the procurement contract in some scientific studies is proposed to supplement formula (3) with the corresponding numerical coefficients. However, it should be noted that the latter will not always be correct, since the law only specifies their thresholds, whereas customers may, at their discretion, set any (smaller) amount of collateral. In addition, after signing by the supplier-winner of the contract of procurement or its execution, expiration of the guarantee and the occurrence of some other conditions, the indicators related to the cost of tender security and enforcement of the contract are subject to return.

The electronic procurement system established in Ukraine does not guarantee the absence of corruption on the part of users, namely, specific customers and suppliers. Their actions require constant monitoring, in particular from the public side. At the same time, the supervisory and control bodies can have a significant influence on the efficiency of public procurement in our country. To date, the Antimonopoly Committee, the Accounting Chamber, the Ministry of Economic Development and Trade, the State Audit Office of Ukraine, the State Treasury of Ukraine, law enforcement agencies (National Anti-Corruption Bureau of Ukraine, National Police of Ukraine, Security Service of Ukraine, prosecutor's offices, etc.), control public procurement of Ukraine. In addition, a significant number of public organizations have been involved in the monitoring of procurement, including the Center for Combating Corruption (www.antac.org.ua), Transparency International Ukraine (www.ti-ukraine.org), Eidos Center for Political Studies and Analytics (www.eidos.org.ua). The most important effect of such regulation should be the saving of public funds in the public sector of the economy. Prices for goods, works and services in the private and public services markets should be brought closer together as a result of the liberalization of the latter and the creation of a competitive environment for them. But, as practice shows, due to the excessive number of controlling bodies, the effectiveness of public procurement procedures is reduced. This is primarily due to duplication of certain functions and uncoordinated assessments for the same problems, the presence of significant deficiencies in the system of appeal of procurement, which leads to excessive spending of resources, a decrease in the overall efficiency of the solution of issues, etc. 


\section{CONCLUSION}

Thus, as evidenced by the results of the study, the introduction of the ProZorro system provides a solid foundation for successfully solving the problem of increasing competition in public procurement. The concentration of supervisors on the issue of ensuring the integrity and transparency of the procurement process promotes the activities of government institutions in the gradual overcoming of the chronic shortage of financial resources, turning the public procurement procedure into a powerful tool for highly effective economic development, based on the high level of competitiveness of the parties formulating commodity/service offers.

The use of a number of principles of prudential management in the smooth functioning of the public procurement mechanism is objectively contributing to the processes of modernizing public administration, which is most clearly manifested in simplifying procedures and maximizing the use of e-government and commerce in public procurement, minimizing the likelihood of corrupt practices, raising the level transparency of the market and creation of a real competitive environment in the field of public procurement.

It should be noted separately that the use of the module of analytics provides the opportunity to calculate the one-time (for a separate purchase), as well as the total (from the use of the system for a certain period of time) savings from the use of this system.

These estimates of absolute and relative economy and performance indicators open tenders in the Ukraine' public sector before and after the introduction of e-procurement "ProZorro" indicate that the first results of the system demonstrate the negative trend of competition and reduction in savings of public funds. The increase in number of ads makes it possible to conclude that the system "ProZorro" is becoming increasingly popular with customers, but because of the excessive number of regulatory bodies, duplication of certain functions and inconsistent estimates of the same problems the efficiency of public procurement procedures can be reduced.

Prospects for further research in this area is to develop an integrated indicator of the effectiveness of the system of public procurement, which takes into account the direct and indirect economic effects. At the same time, it is important that the winner is chosen not only at the lowest offered price, but also on the overall economic efficiency of the offer. An important component in the system for evaluating the effectiveness of public procurement is the analysis of the use of non-price criteria by customers. The logic of evaluating the effectiveness of the procurement system using performance indicators conducted bidding is to determine the proportion of procedures that have not been canceled. Other approaches should be used to evaluate the effectiveness of participation in public procurement for the direct participants in the procedures.

Constant monitoring of public procurement procedures, including with the broadest possible participation, able to cause a significant positive impact not only on the effectiveness of these procedures, but also on the overall performance of supervision and control in the field of establishing state regulation of market economy, transfer it to a higher, more complete, level of development. The most important effect of such regulation should be the saving of public funds in the public sector of the economy.

\section{REFERENCES}

1. Falko, Yu. V. (2014)

Організація державних

закупівель: зарубіжний досвід та практика України [Orhanizatsiia derzhavnykh zakupivel: zarubizhnyi dosvid ta praktyka Ukrainy].
Universytetski naukovi zapysky, 1(49), 261-269.

2. Fedulova, L. I. (2011). Державні закупівлі як засіб стимулювання інноваційної діяльності [Derzhavni zakupivli yak zasib stymuliuvannia innovatsiinoi diialnosti]. Stratehichni priorytety 3(20), 69-75.

3. GDP of Ukraine in current US Dollars. Retrieved from http://data.worldbank.org/ indicator/NY.GDP.MKTP. $\mathrm{CD}$ ?locations=UA 
4. Hassana, H., Tretiakov, A, Whiddett, D., \& Adon, I. (2014). Extent of e-procurement use in SMEs: A descriptive study. Procedia - Social and Behavioral Sciences, 164, 264-270.

5. Holovanenko, M. V. (2016). Ефективність державної закупівельної логістики в умовах запровадження системи "Прозорро" [Efektyvnist derzhavnoi zakupivelnoi lohistyky $v$ umovakh zaprovadzhennia systemy "Prozorro"]. Retrieved from http://tppe.econom.univ.kiev.ua/ data/2016_33/zb33_08.pdf

6. Ishak, M. W., \& Said, J. (2015). Assessing the Role of AntiCorruption Initiatives in Reducing Lobbyist Involvement. E-Procurement: A Case Study of Mardi Procedia Economics and Finance, 31, 485-494

7. Kliuvak, O. V. (2017). Діагностика тендерного забезпечення підприємств у системі електронних публічних закупівель [Diahnostyka tendernoho zabezpechennia pidpryiemstv u systemi elektronnykh publichnykh zakupivel]. Mizhnarodnyi naukovyi zhurnal "Internauka", 3(2), 108-114.

8. Martynovych, D. Ye. (2016). Аналіз ефективності публічних закупівель як інструменту державної допомоги [Analiz efektyvnosti publichnykh zakupivel yak instrumentu derzhavnoi dopomohy]. Investytsii: praktyka ta dosvid, 18, 70-76.

9. Miniailo, V. P. (2010). До питання оцінки ефективності державних закупівель [Do pytannia otsinky efektyvnosti derzhavnykh zakupivel]. Ekonomichni nauky. Seriia "Oblik i finansy", 7(25), 305-313. Retrieved from http://nbuv.gov. ua/UJRN/ecnof_2010_7(2)__39.

10. Melnykov, O. (2012). Оптимізація процедур проведення конкурсних торгів[Optymizatsiia protsedur provedennia konkursnykh torhiv]. Efektyvnist derzhavnoho upravlinnia, 30, 422-430.
11. Melnykov, O. S. (2016). Особливості публічних закупівель як об'єкта державного регулювання економіки [Osoblyvosti publichnykh zakupivel yak obiekta derzhavnoho rehuliuvannia ekonomiky]. Teoriia ta praktyka derzhavnoho upravlinnia, 1, 129-135.

12. Official website of the European Commission. Public Procurement. Retrieved from http://ec.europa. eu/growth/single-market/publicprocurement_en

13. Official website of the European Commission. Public procurement in Europe. Cost and effectiveness. Retrieved from http://ec.europa. eu/internal_market/publicprocurement/docs/modernising rules/costeffectiveness_en.pdf

14. The European Union. Report for selected country groups and subjects. Retrieved from http:// bit.ly/2mYKetA

15. Tosko, R. R. (2017). Кластерний аналіз корупційних ризиків публічних закупівель на макро-, мезо-, мікрорівнях для стабілізації економічної безпеки України [Klasternyi analiz koruptsiinykh ryzykiv publichnykh zakupivel na makro-, mezo-, mikrorivniakh dlia stabilizatsii ekonomichnoi bezpeky Ukrainy]. Derzhavnoupravlinski studii, 1. Retrieved from http://nbuv.gov.ua/UJRN/ deruprs_2017_1_13

16. Uddin, M. (2015). The Prospects and Challenges of e-Procurement in Government purchases: a study on e-Procurement in LGED. Retrieved from http://hdl.handle. net/10361/4273

17. Urjumelashvili, T., \& Marghania, D. (2015). Open contracting in Ukraine: A collaborative effort for procurement reform. Retrieved from http://bit.ly/2opaaPo

18. van der Westhuizen, C. (2015). Monitoring public procurement in South Africa: A reference guide for civil society organizations. Retrieved from http://bit. ly/2onsR67

19. Yuzevych, V. M., Kliuvak, O. V., \& Skrynkovskyi, R. M. (2016).
Діагностика системи взаємодії держави та бізнесу в аспекті електронних публічних закупівель [Diahnostyka systemy vzaiemodii derzhavy ta biznesu v aspekti elektronnykh publichnykh zakupivel]. Ekonomichnyi chasopys-XXI, 160, 39-45.

20. Звіт щодо аналізу функціонування системи державних закупівель за січень-грудень 2015 року. Офіційне інтернетпредставництво Міністерства економічного розвитку і торгівлі України [Zvit shchodo analizu funktsionuvannia systemy derzhavnykh zakupivel za sichen-hruden 2015 roku. Ofitsiine internetpredstavnytstvo Ministerstva ekonomichnoho rozvytku i torhivli Ukrainy]. Retrieved from http://me.gov.ua/Documents/Download?id=fed89cd3eee0-4a37-9eba-1d37782e36fa

21. Звіт сфери публічних закупівель за 2016 рік. Аналітичний звіт. Офіційне інтернет-представництво Міністерства економічного розвитку і торгівлі України [Zvit sfery publichnykh zakupivel za 2016 rik. Analitychnyi zvit. Ofitsiine internet-predstavnytstvo Ministerstva ekonomichnoho rozvytku i torhivli Ukrainy]. Retrieved from http://www. me.gov.ua/Documents/ Download?id=2659335d-238e$443 c-b 4 e a-e 54 f c 621 a b f b$

22. Державна служба статистики України [Derzhavna sluzhba statystyky Ukrainy]. Здійснення державних закупівель в Україні [Zdiisnennia derzhavnykh zakupivel v Ukraini]. Retrieved from http://www.ukrstat.gov.ua

23. Державна служба статистики України [Derzhavna sluzhba statystyky Ukrainy] Індекси споживчих цін у 1992-2017 pp. [Indeksy spozhyvchykh tsin u 1992-2017 rr.]. . Retrieved from http://www.ukrstat.gov.ua

24. Офіційний сайт модуля аналітики системи "Прозорро" 
[Ofitsiinyi sait modulia analityky systemy "Prozorro"]. Retrieved from https://bi.prozorro.org

25. Про публічні закупівлі [Pro publichni zakupivli]. Закон України № 922-VIII від 25.12.2015 [Zakon Ukrainy No 922-VIII vid 12/25/2015].

Retrieved from http://zakon3. rada.gov.ua/laws/show/922-19
26. Реформа публічних закупівель в Україні та результати роботи електронної системи Prozorro (серпень-грудень 2016 року). Аналітичний звіт. Офіційне інтернет-представництво Transparency International Україна [Reforma publichnykh zakupivel v Ukraini ta rezultaty roboty elektronnoi systemy Prozorro (serpen-hruden 2016 roku). Analitychnyi zvit. Ofitsiine internetpredstavnytstvo Transparency International Ukraina]. Retrieved from https://tiukraine.org/wp-content/ uploads/2017/05/Zvit-ProZorro-2016.pdf 